\title{
Curricula reform needed to develop more tech-savvy physicians
}

I $\mathrm{n}$ a bid to redress deficiencies in the ability of future physicians to utilize electronic technologies for health purposes, Canada Health Infoway and the Association of Faculties of Medicine of Canada (AFMC) will examine curricula reform at the nation's medical schools.

Calling ehealth technologies "the new stethoscope,” Jennifer Zelmer, Infoway’s senior vice-president for clinical adoption and innovation, told a symposium in Toronto, Ontario, in May that the lack of physician training represents a substantial barrier in Canada's efforts to implement ehealth technologies.

The need for educational reforms became evident after consultation with clinicians, she added. "It's not helpful that those coming through training only get access [to health information technologies] after graduation," Zelmer said, noting that there is a growing disconnect between high-tech clinical realities and low-tech medical education.

Physicians require information technology competence and training in much the same manner as they require training regarding the "soft skills" needed to treat patients, Zelmer said. With respect to electronic medical records, such skills can be as basic as knowing where in a clinic to place a computer screen with patient data on it.

The joint Infoway/AFMC project will be guided by a committee including faculty from five medical schools, says Catherine Pierce, AFMC project manager for e-Learning. The aim, says Pierce, is to encourage schools to embed training on effective use of information technologies into existing courses, rather than to create new ones.

Among the objectives of the joint project, to which AFMC says Infoway is contributing \$200 000, is identifying "the medical informatics curriculum, related pedagogical resources, and core competencies addressing electronic health records" (http://chec-cesc.afmc.ca

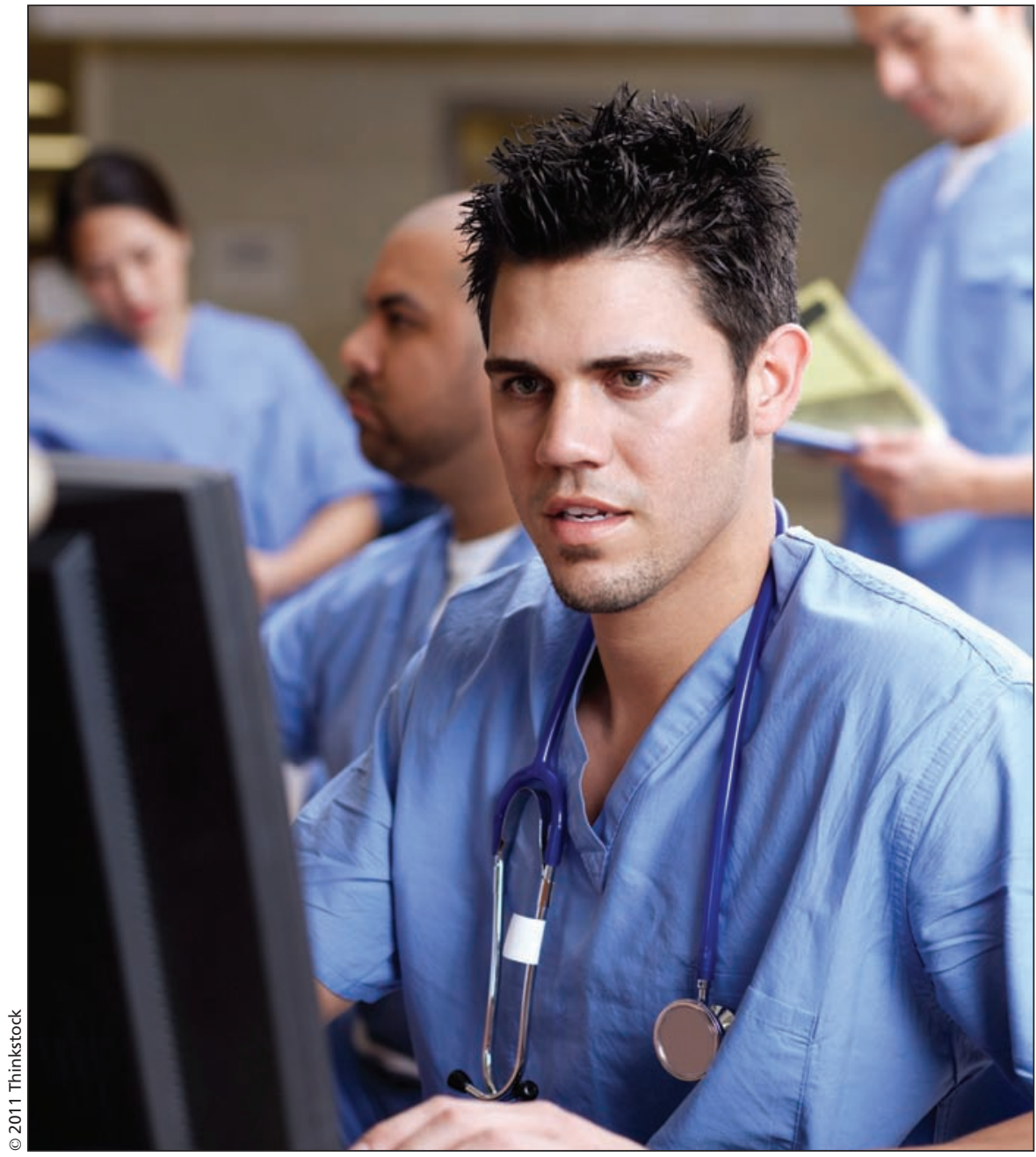

The lack of physician training in information technology represents a substantial barrier to Canada's efforts to implement ehealth technologies.

/community/afmc-infoway-physician-in -training-e-health-curriculum-e-learning).

Infoway has long been aware that without training programs, ehealth reforms will be difficult to accomplish. In a 2009 presentation to federal officials, Mike Sheridan, the agency's chief operating officer, identified "insufficient skilled human resources ... slower than expected clinician uptake ... (and) failure to demonstrate expected benefits" as barriers to clinical use of ehealth technologies.

The need for improved training is obvious, Dominic Covvey, president of the National Institutes of Health Informatics, told the launch of the Infoway-AFMC initiative. Substantial efforts are needed to address a major skills gap in Canadian health care, Covvey warned. Tens of thousands of "ehealth professionals" and thousands of "health informatics professionals" are needed, while all physicians must become "informatics-enabled."

He said in a later interview that federal and provincial officials may have overlooked the training needs of clinicians over the last decade, even while 
investing billions of dollars in ehealth hardware: "The biggest failure is their inability to see clinicians as members of the ehealth team. Imagine the physician who is not stethoscope-enabled."

Some provinces, though, appear to have made some inroads into ehealth training. Efforts to integrate ehealth into medical education have been ongoing at the University of Alberta in Edmonton for at least four years, says Robert Hayward, associate dean of clinical informatics at the institution.

The trigger for those efforts was a meeting in which provincial health officials expressed alarm that technology investment was outstripping workforce capacity, says Hayward, a member of the Infoway/AFMC project steering committee.

The university's medical faculty subsequently conducted a curriculum review which led to the adoption of six ehealth modules embedded in existing courses, he says. The modules address the management of personal health information, shared information, clinical information support, decision support and information technology. Students are subsequently certified according to five levels of competency, he adds. "Not everyone wants to do this at the same level."

Hayward adds that the national challenge of making health care providers ehealth-literate is daunting. "The workforce is still functionally illiterate."

Moreover, the lack of clinician uptake of electronic health technologies is a severe problem that government strategies have overlooked and must address, Hayward argues. "It's still mind-blowing to patients. ... The biggest challenge is not to be bitter about it."

Several other institutions are also moving to redress the shortfall. The University of British Columbia is now con- ducting a curriculum review designed to embed ehealth in the school's four-year medical program, says Dr. Kendall Ho, director of the eHealth Strategy Office at UBC's Faculty of Medicine. Reforms are expected to be introduced in 2012.

Ho, who is also a member of the Infoway/AFMC project steering committee, blames the long lag time in moving to integrate ehealth into medical education on confusion over federal and provincial strategies to promote clinical adoption of ehealth technologies, and questions "about how much money is being allocated" for clinical adoption.

The modest Infoway/AFMC initiative may signal that more monies may soon flow toward the problem, Ho says. "There is some excitement that Infoway is now willing to invest." - Paul Christopher Webster, Toronto, Ont.

CMAJ 2011. DOI:10.1503/cmaj.109-3913

Editor's note: Twenty-first in a series on electronic health records

Part I: Canada's electronic health records initiative stalled by federal funding freeze (www.cmaj.ca/lookup/doi/10.1503/cmaj.109-3183)

Part II: Ontario's plan for electronic health records is at risk, official says (www.cmaj.ca/lookup/doi/10.1503/cmaj.109-3193)

Part III: Electronic health records a "strong priority" for US government (www.cmaj.ca/lookup/doi/10.1503/cmaj.109-3218)

Part IV: The pocketbook impact of electronic health records: PRO (www.cmaj.ca/lookup/doi/10.1503/cmaj.109-3225)

Part V: The pocketbook impact of electronic health records: CON (www.cmaj.ca/lookup/doi/10.1503/cmaj.109-3226)

Part VI: National standards for electronic health records remain remote (www.cmaj.ca/lookup/doi/10.1503/cmaj.109-3239)

Part VII: National electronic health records initiative remains muddled, auditors say (www.cmaj.ca/lookup/doi/10.1503/cmaj.109-3242)

Part VIII: New electronic health record blueprint to call for increased patient participation

(www.cmaj.ca/lookup/doi/10.1503/cmaj.109-3265)

Part IX: Albertans to gain electronic access to personal health files (www.cmaj.ca/lookup/doi/10.1503/cmaj.109-3270)

Part X: Canadian hospitals make uneven strides in utilization of electronic health records (www.cmaj.ca/lookup/doi/10.1503/cmaj.109-3288)

Part XI: United States to compel physicians to make "meaningful use" of electronic health records (www.cmaj.ca/lookup/doi/10.1503/cmaj.109-3361)

Part XII: Canada's ehealth software “Tower of Babel”' (www.cmaj.ca/lookup/doi/10.1503/cmaj.109-3717)

Part XIII: National electronic health information strategy needs to be refocused, critics say (www.cmaj.ca/lookup/doi/10.1503/cmaj.109-3744)

Part XIV: Seeing is Belizing (www.cmaj.ca/lookup/doi/10.1503/cmaj.109-3782)

Part XV: Experts call for health infoway "watchdog” (www.cmaj.ca/lookup/doi/10.1503/cmaj.109-3783)

Part XVI: Infoway tacks towards “networked” patients (www.cmaj.ca/lookup/doi/10.1503/cmaj.109-3798)

Part XVII: Medical data debates: Big is better? Small is beautiful? (www.cmaj.ca/lookup/doi/10.1503/cmaj.109-3799)

Part XVIII: Audit concludes Infoway missed performance targets (www.cmaj.ca/lookup/doi/10.1503/cmaj.109-3860)

Part XIX: Go local, European review of electronic health records advises (www.cmaj.ca/lookup/doi/10.1503/cmaj.109-3861)

Part XX: Administrator urges penalties for doctors who don't use electronic medical records

(www.cmaj.ca/lookup/doi/10.1503/cmaj.109-3914) 